\title{
Quick Submit i OJS 3
}

For at påbegynde en 'Quick Submit' skal du i venstremenuen vælge linket 'Værktøjer' > 'Importér/Eksportér' ('Tools' > 'Import/Export'). På den fremkomne side vælger du linket 'QuickSubmit Plug-in'

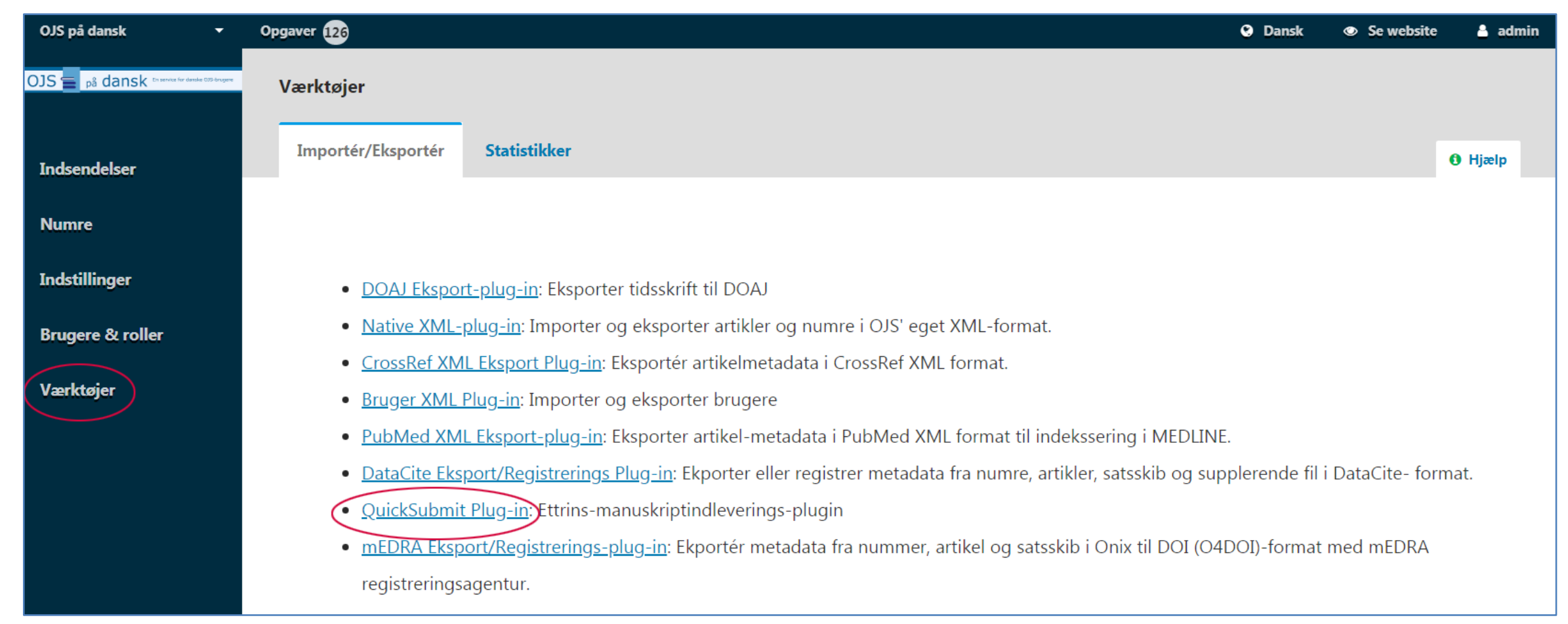


Herved fremkommer QuickSubmit-siden hvor al metadata indskrives og manuskriptfilen hentes ind. Denne side minder i store træk om den tilsvarende side i OJS 2-udgaven. Bemærk dog at feltet, hvor man uploader manuskriptet nu er placeret længere nede på siden med linket Add galley/Tilføj publiceringsversion

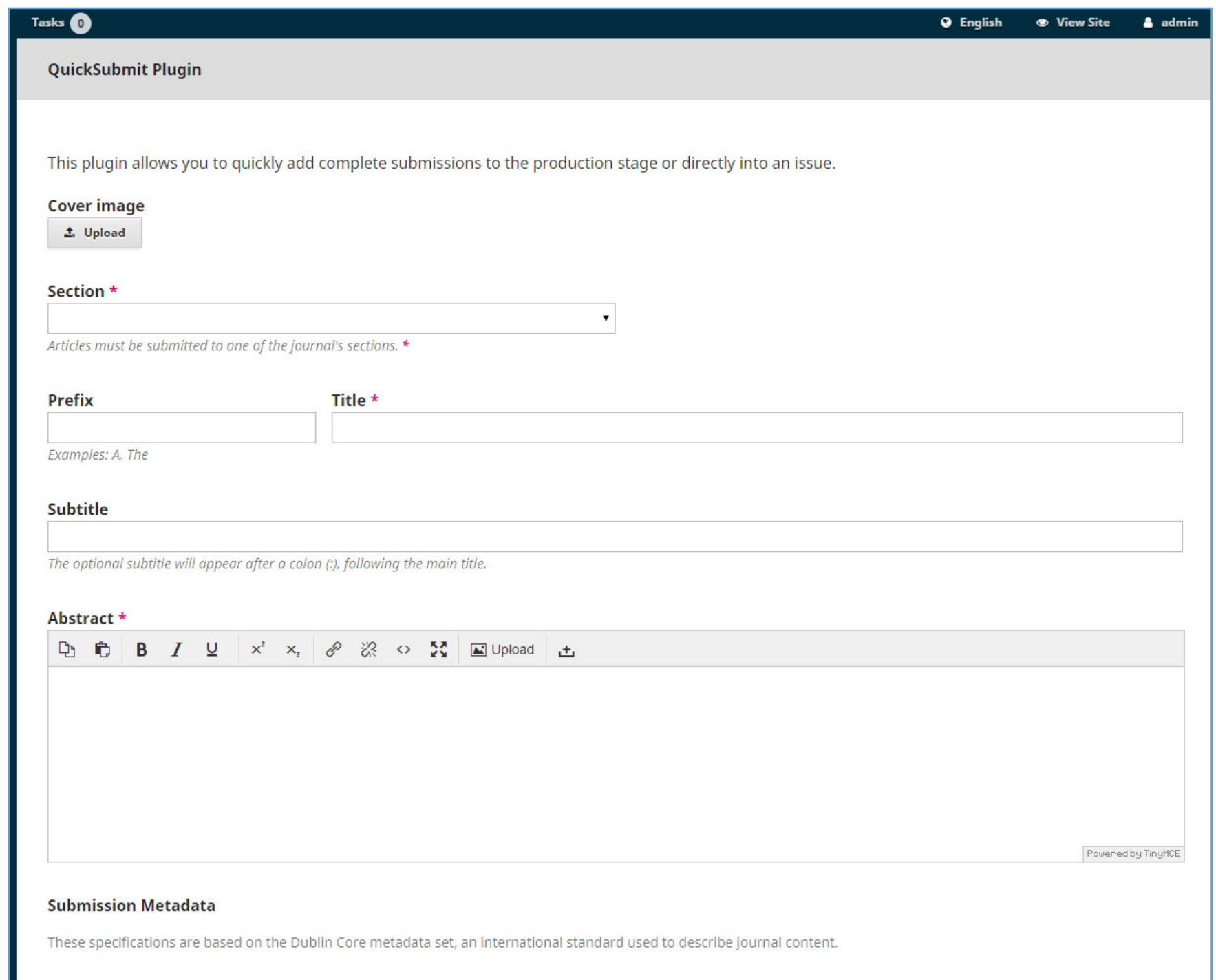


Under List of Contributors/Liste over bidragydere klikkes på linket Add Contributor/Tilføj bidragyder, hvorved en ny side popper op. På denne indsætter du forfatternavn mm.

Under Galleys/Publiceringsversioner aktiverer du linket Add galley/Tilføj publiceringsversion, hvorefter du kan uploade dit manuskript. Dernæst klikker du på 'Save'

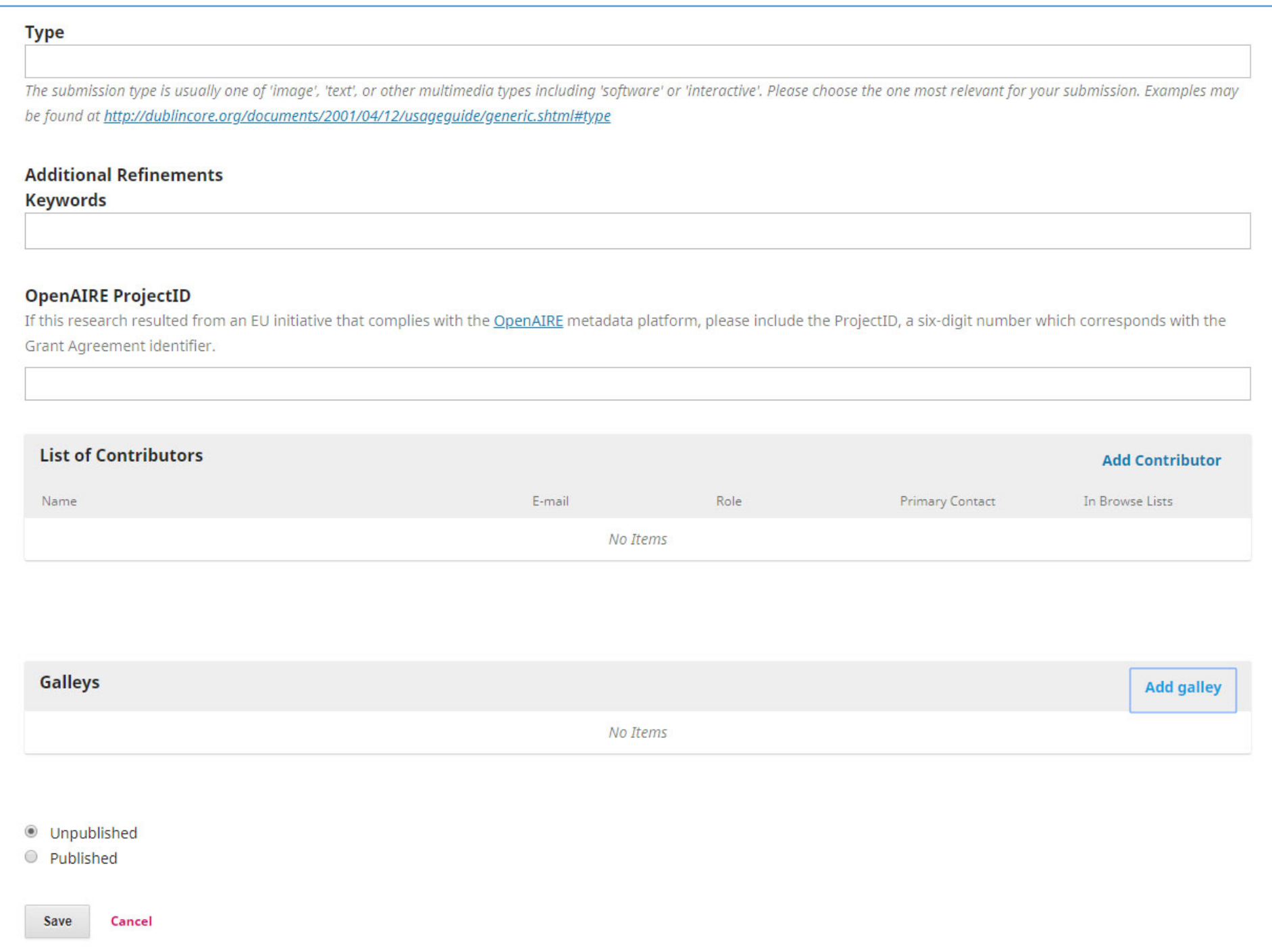


Du får nu to valgmuligheder, enten kan du påbegynde en ny QuickSubmit, eller du kan gå til Submission/Indsendelser

\begin{tabular}{l|l|}
\hline OJS på dansk & Tasks 0 \\
\hline Submissions & Article Added \\
Issues & Article creation was successful. \\
Payments & \\
Settings & \\
Users \& Role Submission to QuickSubmit plugin. \\
Tools
\end{tabular}


Her vælges Go to Submission/Gå til Indsendelser, hvorved du når frem til produktionssiden. Såfremt du endnu ikke har oprettet det nummer, som manuskriptet skal lægges i, skal dette gøres, inden du klikker på knappen Schedule For Publication/Planlæg publicering. Herefter kan du lægge manuskriptet i det $\emptyset$ nskede nummer via Schedule For Publication/Planlæg publicering

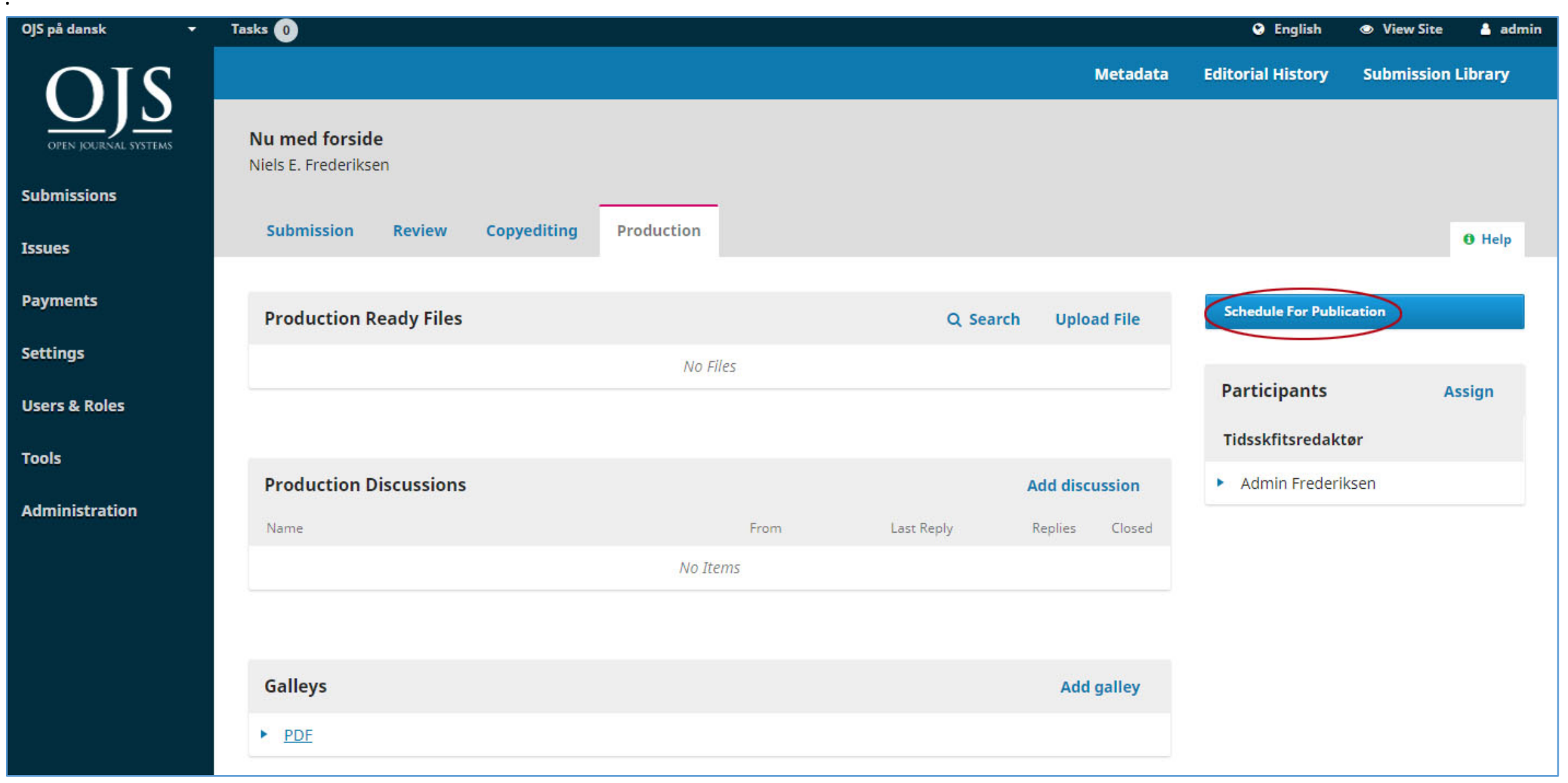


Det sker her:

Publication

Schedule for publication in

-..-- Future Issues --..-.

To Be Assigned *

Pages

Pages

\section{Permissions}

$\square$ Attach the following permissions to the submission:

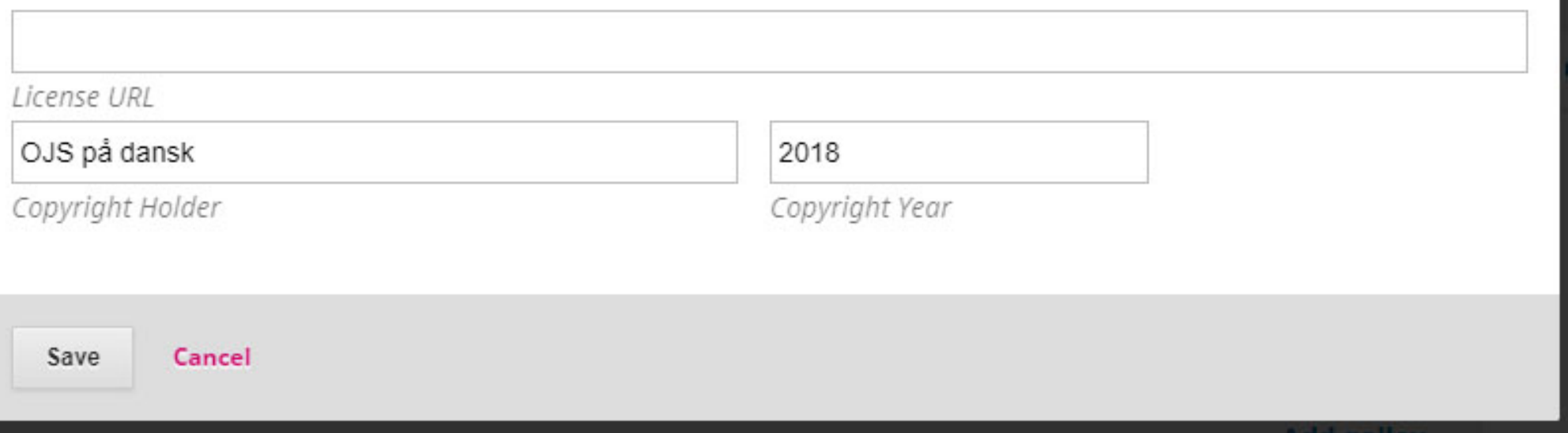


Såfremt du ønsker at lægge manuskriptfilen i et allerede oprettet nummer - det gælder såvel fremtidige som tidligere numre - skal du markere knappen 'Published/Publiceret' hvorefter du allerede på QuickSubmit-siden får mulighed for at vælge nummer og tilføje de nødvendige oplysninger.

To Be Assigned *

Pages

Pages

Permissions

License URL 